\title{
MODELLING OF THEMATIC DIGITAL ATLAS OF THE BOKA KOTORSKA GULF WITHIN GEOGRAPHIC INFORMATION SYSTEM
}

\author{
Nikola Stamenković, Svetislav Šoškić, Miodrag Kostić, Ljubomir Gigović, Miodrag Regodić, Saša Bakrač
}

Professional paper

This paper presents a possibility of creating and compilation of digital cartographic products of certain geographic area using modern cartographic approach along with the use of traditional cartographic methods and procedures within certain GIS software. Within the system of cartographic and GIS methods this paper presents analogue-digital conversion of cartographic data, defining and control of mathematical elements of atlas maps, processing and generating of geographic atlas content of the Gulf. In this paper multifunctionality and different aspects of using obtained digital geodata are presented through the project of modelling and creating Digital atlas of the Boka Kotorska Gulf regardless of the epoch of formation of the basic cartographic sources because the changes occurring are not the same in the case of all geographic map elements. The advantages of modelling thematic atlas within applied system of cartographic and GIS methods are listed what represents the way for getting new charts and new data about quantitative and qualitative characteristics of certain geographic phenomena of the Gulf.

Keywords: Boka Kotorska Gulf; digital atlas; geographic information system; modelling; thematic map

Modeliranje tematskog Digitalnog atlasa Bokokotorskog zaljeva u okviru geografskog informacijskog sustava

Stručni članak

U radu je prikazana mogućnost izrade i kompilacije digitalnih kartografskih proizvoda određenog geografskog područja suvremenim kartografskim pristupom uz uporabu tradicionalnih kartografskih metoda i postupaka u okviru određenog GIS softvera. U okviru sustava kartografskih i GIS metoda u radu je prikazana analogno-digitalna konverzija kartografskih podataka, definiranje i kontrola određenih matematičkih elemenata atlasnih karata i obrada te generiranje geografskog sadržaja atlasa Zaljeva. Kroz projekt modeliranja i stvaranja Digitalnog atlasa Bokokotorskog zaljeva u radu se prikazuje multifunkcionalnost i mnogoaspektnost uporabe dobivenih digitalnih geopodataka iz atlasa, bez obzira na epohu nastajanja osnovnih kartografskih izvora atlasa, jer promjene koje se događaju nisu iste kod svih geografskih elemenata karata. Navedene su prednosti modeliranja atlasa u okviru primijenjenog sustava kartografskih i GIS metoda što predstavlja način za dobivanje novih karata i podataka o kvantitativnim i kvalitativnim karakteristikama pojedinih geografskih pojava Zaljeva.

Ključne riječi: Bokokotorski zaljev; digitalni atlas; geografski informacijski sustav; modeliranje; tematska karta

\section{Introduction}

The coastline of Montenegro is characterized by two geographically different areas: the Boka Kotorska Gulf and the coast south of this gulf, from Miriste Cape to the estuary of the Bojana River into the Adriatic Sea. The area of Boka Kotorska and the gulf, having the same name, represent one of the most interesting geographic complexes of the Adriatic and Mediterranean Sea. The Boka Kotorska Gulf belongs to the group of the most beautiful world fiords and it is registered in the World Cultural Heritage under UNESCO protection, but, however, the total geographic contents, hydrological and hydrographical phenomena of the Gulf have not been analysed and portrayed enough yet which represents one of the factors having significant influence during research upon the approach to planning, making and atlas remapping of the part of the Gulf area within certain geographic information system (GIS). Modern concepts of making thematic, regional and national atlases are applied by the great number of relevant state cartographic institutions at the global level. Certain models of making thematic atlases and different atlas information systems have been, among others, developed by state cartographic institutions of the Czech Republic [3], Austria [14], and Switzerland [16]. In the second decade of the $21^{\text {st }}$ century, along with the development of the modern technology and global network of Internet, the need for designing of thematic web atlases occurs more and more. As a result of this, development of new concepts of making and structuring of different cartographic digital data is required [18].

\section{Methodology}

The basic research problem which had to be solved during Digital atlas modelling of the Boka Kotorska Gulf is the absence of adequate geodatabase of Boka Kotorska in the structured digital form mainly from hydrographical and cartographic scope of activities. All available geographic data were mainly found in analogue form $[6 \div 11,15]$ which should have been adapted to the modern approach of atlas mapping.

The basic task is to, according to the available basic, additional and auxiliary cartographic data sources, establish the base and structure of thematic Digital atlas of the Boka Kotorska Gulf by application of the computer technology, GIS software, digital cartography i.e. digitalization of phenomena and procedures (vectorization and rasterization), and then by application of system of cartographic methods where modelling methods, comparative and specific geometric methods form part of the mentioned.

Remapping of the Boka Kotorska Gulf area is possible to carry out by collection, analysis and processing of existing and updated data within certain GIS software. Once they were collected, checked, updated and georeferenced bathymetric, hydrographical, oceanographical and topographical data were converted using planned and controlled procedures into vector form, they are placed into spatial data bases which can form the 
basis of modelling and development of thematic Digital atlas of the Boka Kotorska Gulf within geographic information system.

\section{Cartographic project of Digital atlas of the Boka Kotorska Gulf}

Considering the aspects of using maps, certain authors conclude that pieces of information contained in maps can be translated into the other languages which enable different aspects of their use and including in the other systems of sciences [19]. This can especially refer to the thematic Digital atlas of the Boka Kotorska Gulf. Traditional definition of geographic atlases says that they are collections of geographic maps which, concerning their contents, purpose, editorial solutions and resources, form unique entities, and all atlas maps, as parts of atlas, had to be made meaningfully equal to each other, mutually complemented and coordinated [13]. Special attention is drawn to the characteristics and level of generalization of content of thematic atlas maps. Digital atlases can be characterized even by the feature of multimedia, and in the certain cases they can be directly connected to cartographic information systems and spatial data base without which it is not possible to determine them notionally.

Digital cartographic systems can be, and they are the most often, cartographic subsystems within GIS, so that besides the other possibilities which digital mapping gives by means of GIS, the analysis of spatial data is also possible [2]. Atlas maps of Digital atlas of the Boka Kotorska Gulf were made using GeoMedia Professional GIS software and the goal of cartographic project was as follows:

- Formation of adequate geographical data bases as possible fundamentals for creation of marine GIS of the Boka Kotorska Gulf;

- Obtaining of certain number of thematic atlas charts in vector digital form and in the traditional paper version (Atlas charts - Fig. $1 \div 6$ );

- Obtaining of certain number of thematic marine navigational plans and charts in analogue and digital form such as plans of harbours, little ports, marinas, coves, passages and anchorages in the gulf (at different scale).

Carrying out of different cartographic works and activities such as examination, finding solution and final defining of the number of working versions of atlas charts which can be instantaneously made and determination of territory of mapping of certain geographic charts in the atlas i.e. division on the sheets of territory of mapping, was considered under realization of the mentioned goal of project. It was necessary to carry out analysis, evaluation and selection of cartographic sources along with the study of territory of mapping in order to apply the principle of cartographic generalization of geographic elements and to solve mathematical elements of certain chart types. The important activities concerning cartographic project are also finding solution of the way how to show certain geographic elements on the atlas charts, marking the charts, then method of expression and shaping of charts, designing of total charts contents (chart frame, contents within the chart frame, in the chart frame and out of chart frame) and determination of atlas chart making procedure by using GIS techniques i.e. by application of digital cartography.

Mathematical, geographic and art elements of atlas charts were taken into consideration by making digital atlas of the Boka Kotorska Gulf, and solutions which were given could not be without mutual influence of mentioned group of elements. Atlas belongs to the group of complex thematic atlases and fundamentally processes natural phenomena, but as a result of specific quality of structure and contents of certain authentic marine maps, certain atlas charts can be classified even into thematic maps of technical communications and systems such as Atlas Sheet no. 25-4 i.e. working version of General navigation chart of "Boka Kotorska", published in 2004, at a scale 1:25000 (Fig. 2). Informative and auxiliary maps (sedimentary, bathymetric ones,...) form most of atlas maps, and they find their application by their diversity and contents in the case of wide range of users as well as in the case of narrow range of certain specialists. Besides basic elements of geographic contents, atlas maps also contain thematic contents such as hydrological and hydrographical phenomena of the bay of which, within the atlas, depending on the scale of atlas maps, the following was elaborated in more details: coastal line of the bay, surface of the bay in isobaths, bathymetric information (Fig. 6), surface sediments i.e. type - deposits of the sea bottom (Fig. 3), topography of the sea bottom, relief of coastal land because of its division into sections (Fig. 7) and relation with relief of the sea bottom and constant and periodical river flows (land hydrography).

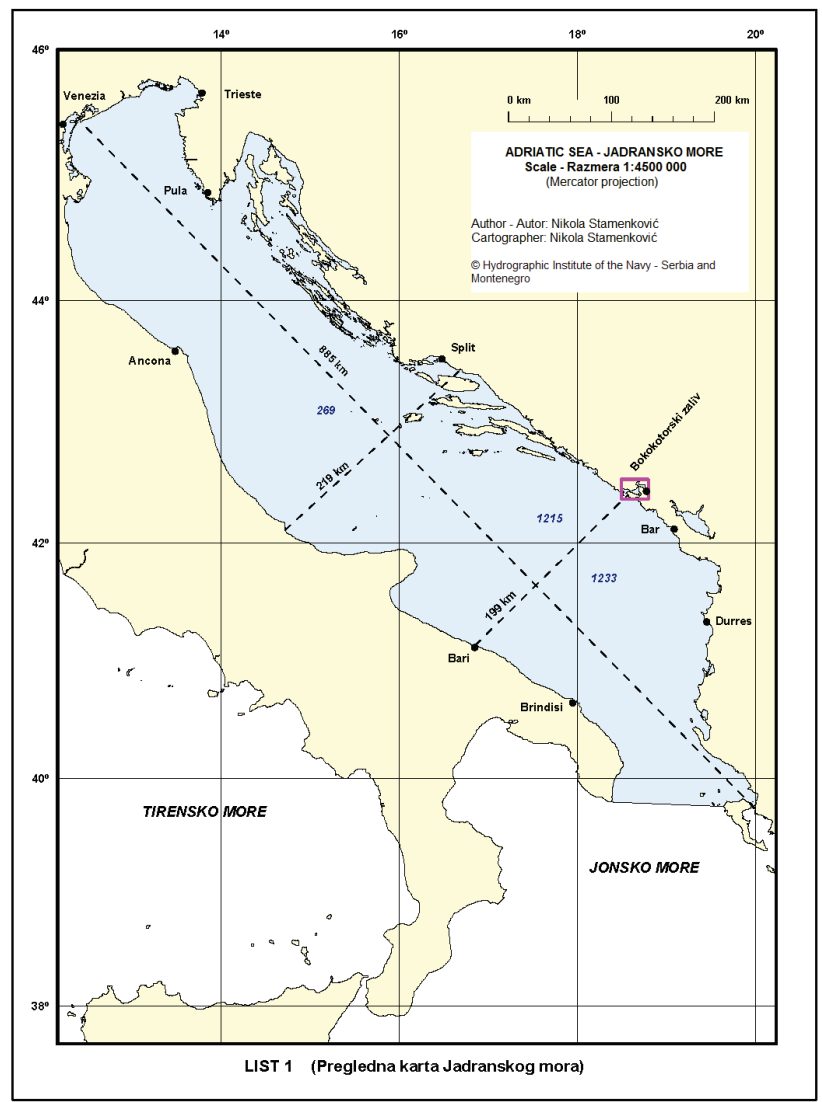

Figure 1 Overview (reduced) map of Digital atlas of the Boka Kotorska Gulf - Position of the Boka Kotorska Gulf 


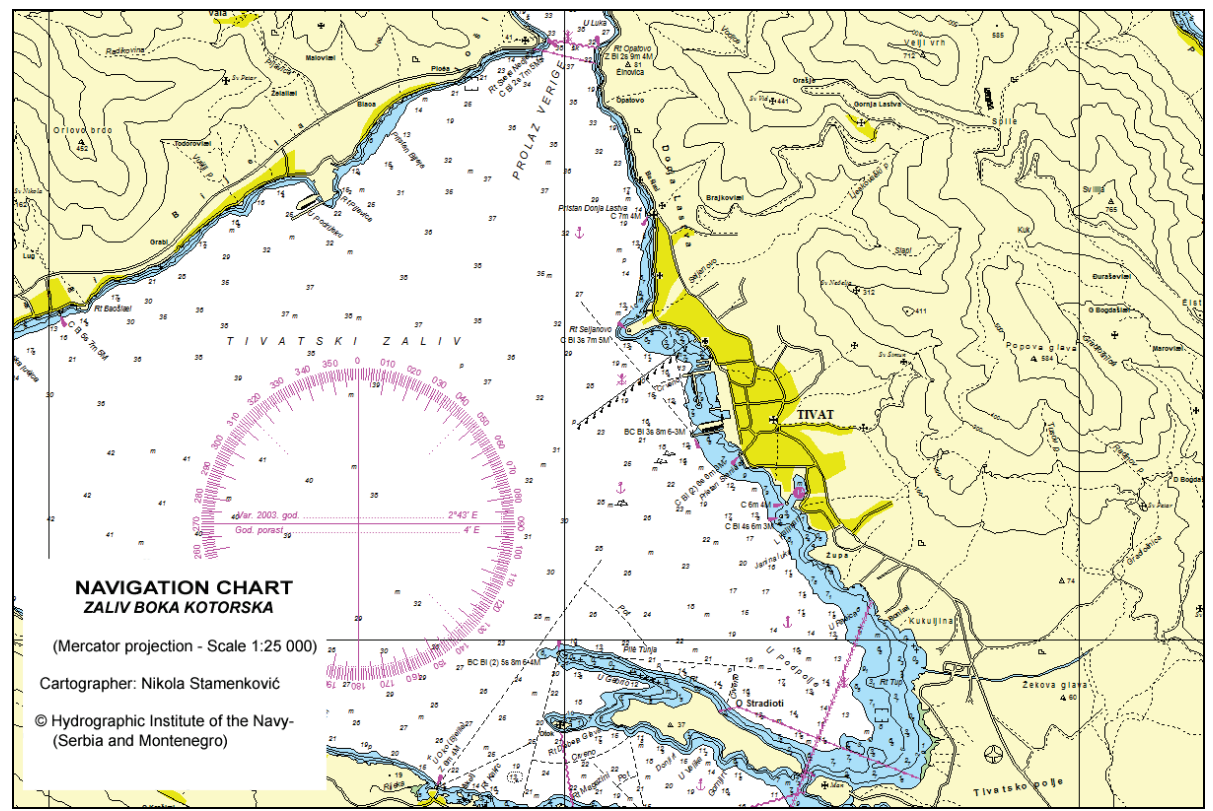

Figure 2 Part of Atlas Sheet no.25-4 (reduced), working version of General navigation chart of the Boka Kotorska Gulf, scale 1:25 000 (published in 2004)

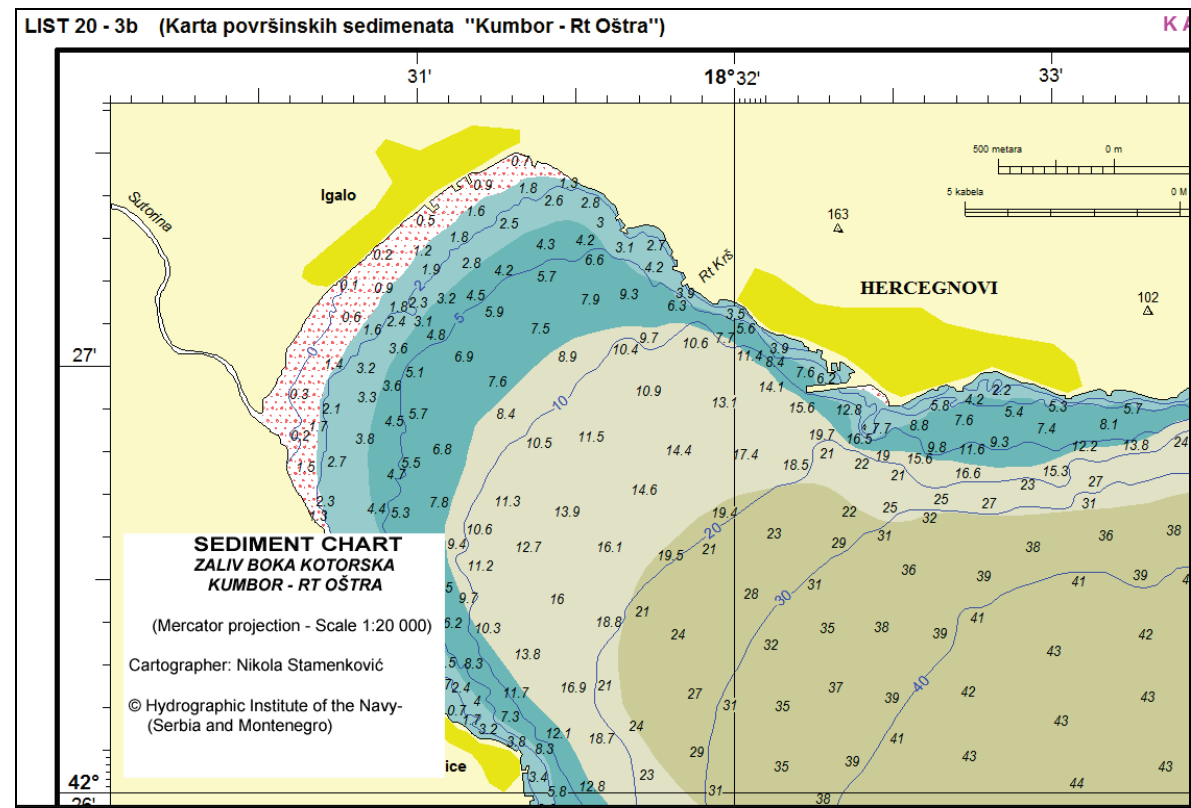

Figure 3 Part of Atlas Sheet no. 20-3b (reduced), working version of "Kumbor - Oštra Cape" map of sea bottom surface sediments, scale 1:20 000, (published in 2004)

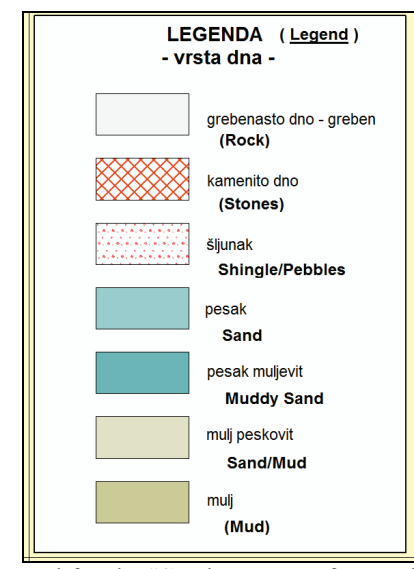

Figure 4 Legend for the "Sea bottom surface sediments" Atlas Sheet no. 20-3b

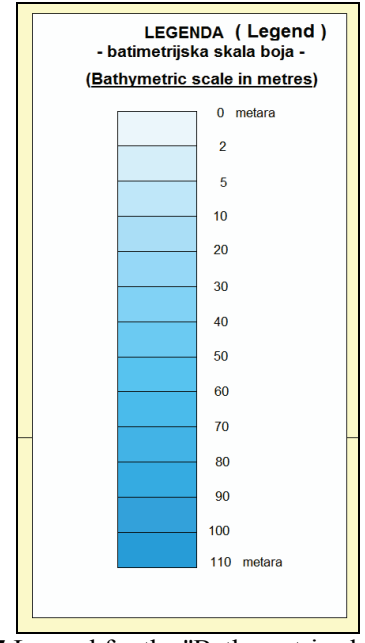

Figure 5 Legend for the "Bathymetric chart" Atlas Sheet no. 20-3a 


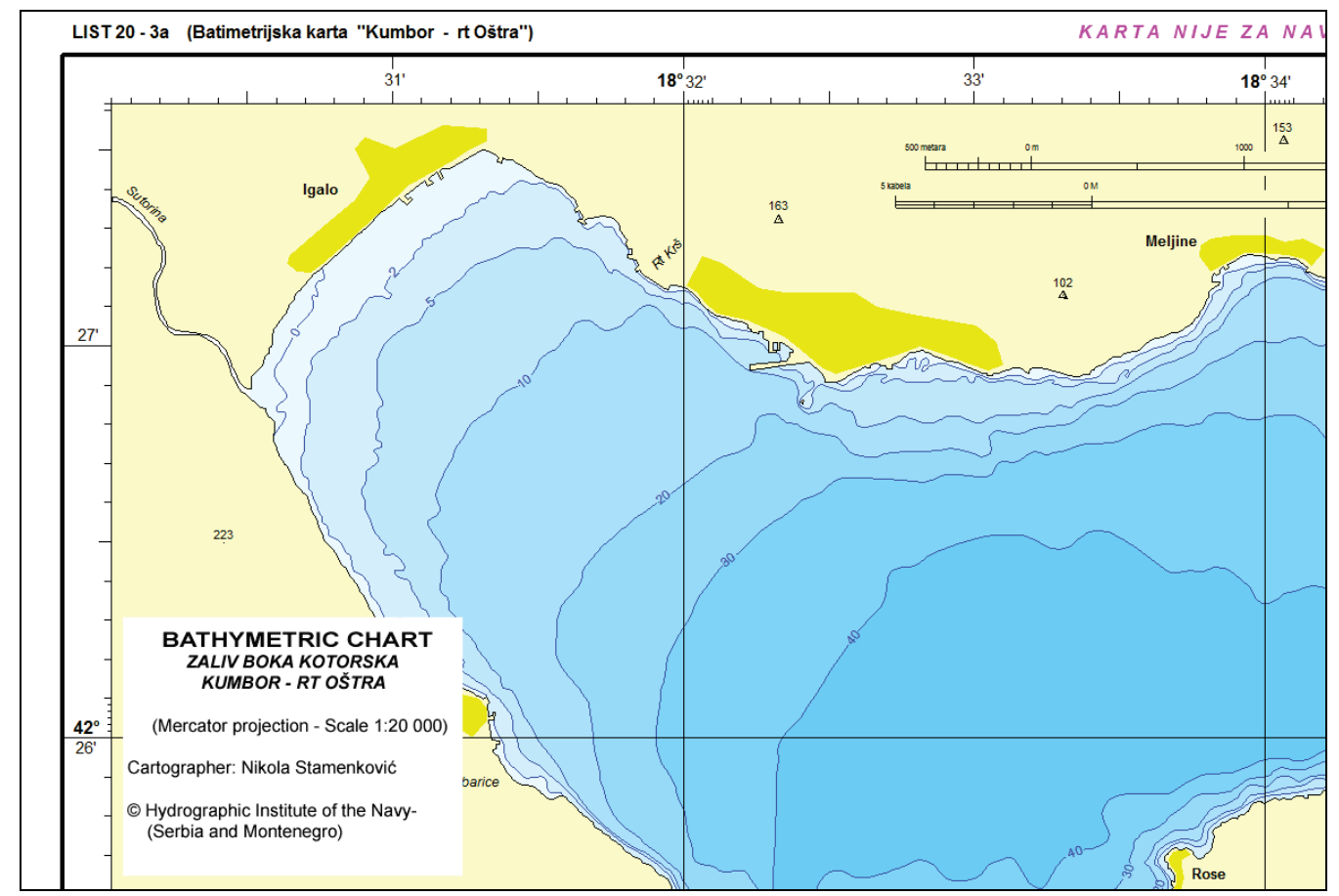

Figure 6 Part of the Atlas Sheet no. 20-3a (reduced), working version of "Kumbor - Oštra Cape" bathymetric chart, at a scale1:20 000, (published in 2004)

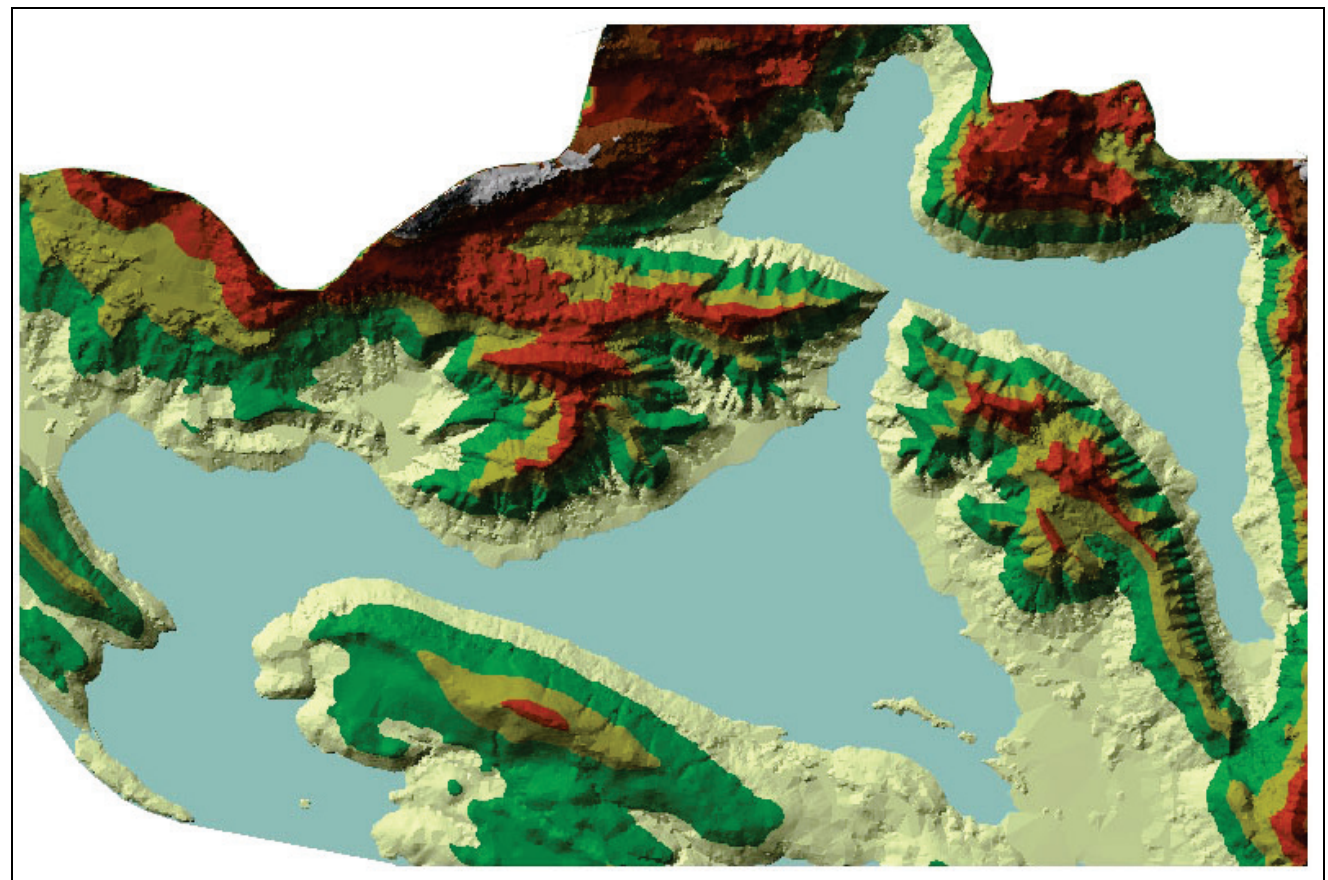

Figure 7 Coastal relief of the Gulf - 3D model (made on the base of contour lines, equidistance of 20 metres)

\subsection{Calculation of mathematical elements of atlas navigation chart of Boka Kotorska}

Calculation of mathematical chart elements was essentially related to the determination of precise values of output parameters of Mercator projection for a particular mapping territory, and which were used for correctly drawing of cartographic graticule of meridians and parallels and their intersected points. Mathematical model research for atlas navigation chart of the Boka Kotorska Gulf was necessary to carry out due to more reasons using special computer program.

The main reason is the lack of published authentic charts as well as physical state in which analogue cartographic material was found, because one of the basic sources for digital atlas chart making is paper sheet of the chart and it was published in 1962. Inadequate conditions of storing, keeping and use of chart, then passed time of over 50 years since their publishing, caused deformations of the chart sheet, and deviations of real dimensions from demanded theoretical sheet values which amounted up to one millimetre. The other reason for calculation of certain mathematical elements results from possibility of applied technology and methods in the construction procedure of frame and graticule of a chart during 1960s. The third reason is the fact that the graticule was, at its basic cartographic source, moved towards the east for 15,4" (351,9 meters) and towards the south for 3,9" (120,3 
meters) and as a result of this it is necessary to carry out additional recalculations when determining and transferring of position from Boka Kotorska chart to navigation chart of smaller scale (with the same mathematical elements).

Modern process of designing and making charts along with the application of computer technology develop in characteristic stages. The stage of determination and checking of mathematical elements of
Boka Kotorska navigation chart implied analogue-digital conversion (i.e. scanning of navigation chart), arranging of scanned image at the rasterization level, construction of mathematical chart basis and fitting of a raster image into designed cartographic graticule and then the so-called "registration" of a chart raster image within GIS software which implies georeferencing and transformation into the adequate projection.

Table 1 Calculated values of translatory moved new cartographic graticule of atlas navigation chart of Boka Kotorska (scale 1:25 000)

\begin{tabular}{|c|c|c|c|c|c|c|}
\hline \multirow[b]{2}{*}{$\begin{array}{l}\text { Parallels } \\
\qquad(\varphi)\end{array}$} & \multirow{2}{*}{$\begin{array}{c}\text { Increased } \\
\text { latitudes } \\
\left(\varphi_{\mathrm{M}}{ }^{\prime}\right)\end{array}$} & \multicolumn{2}{|c|}{ Distance (mm) } & \multirow[b]{2}{*}{$\begin{array}{c}\text { Meridians } \\
\text { (ג) }\end{array}$} & \multicolumn{2}{|c|}{ Distance $(\mathrm{mm})$} \\
\hline & & $\begin{array}{l}\text { From N } \\
\text { neatline }\end{array}$ & $\begin{array}{l}\text { From } \mathrm{S} \\
\text { neatline }\end{array}$ & & $\begin{array}{l}\text { From W } \\
\text { neatline }\end{array}$ & $\begin{array}{l}\text { From E } \\
\text { neatline }\end{array}$ \\
\hline $42^{\circ} 31^{\prime} 19,1^{\prime \prime}$ & 2808,5045 & 0,00 & 609,61 & $18^{\circ} 30^{\prime} 02,0^{\prime \prime}$ & 0,00 & 932,40 \\
\hline $42^{\circ} 31^{\prime} 00^{\prime \prime}$ & 2808,0755 & 23,52 & 586,09 & $18^{\circ} 32^{\prime} 00^{\prime \prime}$ & 107,85 & 824,55 \\
\hline $42^{\circ} 28^{\prime} 00^{\prime \prime}$ & 2804,0218 & 245,81 & 363,80 & $18^{\circ} 35^{\prime} 00^{\prime \prime}$ & 272,35 & 660,05 \\
\hline $42^{\circ} 25^{\prime} 00^{\prime \prime}$ & 2799,9714 & 467,92 & 141,69 & $18^{\circ} 38^{\prime} 00^{\prime \prime}$ & 436,86 & 495,54 \\
\hline $42^{\circ} 23^{\prime} 05,1^{\prime \prime}$ & 2797,3876 & 609,61 & 0,00 & $18^{\circ} 41^{\prime} 00^{\prime \prime}$ & 601,37 & 331,03 \\
\hline & & & & $18^{\circ} 44^{\prime} 00^{\prime \prime}$ & 765,88 & 166,52 \\
\hline & & & & $18^{\circ} 47^{\prime} 00^{\prime \prime}$ & 930,39 & 2,01 \\
\hline & & & & $18^{\circ} 47^{\prime} 02,2^{\prime \prime}$ & 932,40 & 0,00 \\
\hline
\end{tabular}

Construction of the new mathematical chart basis was determined by Mercator projection on the perpendicular cylinder, and one of the goals, in order to determine the correct values of cartographic graticule of atlas map sheet of Boka Kotorska, was to eliminate already mentioned systematic errors appearing during comparison of positions to the other navigation charts of smaller scale. Parameter calculation for cartographic projection was carried out by means of adequate algorithms [12]. Input data for getting and plotting of new cartographic graticule were as follows:

- Parameters of Bessel ellipsoid-Hermannskogel 1841

(equatorial radius - a, polar half-axis - b, eccentricity $-\mathrm{e})$;

- Mapping territory limited by parallels and meridians, i.e. new values were calculated for the vertices of chart $\lambda_{\mathrm{W}}$ and $\lambda_{\mathrm{E}}$ being increased for $\Delta \lambda=+15,4^{\prime \prime}$ and $\varphi_{\mathrm{S}}$ and $\varphi_{\mathrm{N}}$ decreased for $\Delta \varphi=-3,9^{\prime \prime}\left(\lambda_{\mathrm{W}}=018^{\circ} 30^{\prime} 02^{\prime \prime}\right.$, $\left.\varphi_{\mathrm{S}}=42^{\circ} 23^{\prime} 05^{\prime \prime}, \lambda_{\mathrm{E}}=018^{\circ} 47^{\prime} 02^{\prime \prime}, \varphi_{\mathrm{N}}=42^{\circ} 31^{\prime} 19^{\prime \prime}\right)$ and chart scale amounting 1:25 $000(\mathrm{M}=25000)$;

- Chart latitude (parallel) construction $\varphi_{K}$ which is used for calculations of all the other ordinates, and which amounts to $\varphi_{\mathrm{K}}=42^{\circ} 27^{\prime} 00^{\prime \prime} \mathrm{N}$;

- Condition is set for determination of the meridian and parallel values in the interval of 3 arc minutes.

The new cartographic graticule, translatory moved towards the west and the north for certain values (Tab. 1), was obtained as an output result of used algorithm.

Also, due to large scale map and achieving as absolute and relative position precision as possible and fitting of geographic map contents, certain values were calculated as more accurate as possible according to the equation for Mercator projection and above mentioned input data, and as a result the following was obtained:

- $\quad$ Mercator's parameter, $\mu=54,83637 \mathrm{~mm}$;

- Dimensions of useful map format, $x=932,4 \mathrm{~mm} ; y=$ $609,6 \mathrm{~mm}$.

By calculating the difference of geographic longitudes and increased latitudes of the given points from the coordinate beginning of map sheet, for which southwest vertex of the sheet $\left(\varphi_{\mathrm{S}}, \lambda_{\mathrm{W}}\right)$ is taken, the values in the map scale are obtained in millimetres based on the following equations $\Delta X=\mu \times \Delta \lambda^{\prime}$ and $\Delta Y=\mu \times \Delta \varphi_{\mathrm{M}}^{\prime}$, where is: $\Delta \lambda^{\prime}=\lambda-\lambda_{\mathrm{W}}$ and $\Delta \varphi_{\mathrm{M}}^{\prime}=\varphi_{\mathrm{M}}^{\prime}-\varphi_{\mathrm{MS}}^{\prime}$.

One of the advantages of digital cartography is achieved possibility to enable, by analysis and noticing certain kinds of errors on the analogue maps, relatively easy correction of certain errors such as errors resulting from paper chart deformations and specific systematic errors.

\subsection{Evaluation of geometric accuracy of atlas navigation chart of Boka Kotorska}

After error corrections resulting from paper chart deformations and elimination of systematic errors on the basic cartographic sources, it was approached to the evaluation of horizontal accuracy of digital map. Previous accuracy evaluation could not be carried out due to the insufficient knowledge of all operations, methods and stages in the procedure of map making as well as insufficient knowledge of all hydrographic sources which functioned as the basic map source.

Accuracy evaluation was obtained by comparing elements measured on the map with their most possible values which were obtained during field works. Geometric accuracy evaluation was developed in two stages:

- Firstly, the most possible values of parameters were determined for transferring to Bessel ellipsoid from geographic coordinates obtained in relation to WGS84 ellipsoid (horizontal values $\Delta \varphi$ and $\Delta \lambda$ );

- Secondly, horizontal accuracy of certain map elements was determined by the most possible values of errors in relation to Bessel ellipsoid.

At the first stage, it was necessary to determine corrections which should be applied to the positions obtained by means of satellite navigation systems such as GPS (Global Positioning System), due to the fact that 
most of the charts in the atlas were made on the basis of and according to Bessel ellipsoid parameters. Atlas maps of the Adriatic Sea, at a scale 1:1 000 000, are exception to this. They are made according to the geocentric WGS84 ellipsoid parameters because the errors occurring during transformation of geographic content in the frame are allowable values which are common for navigation map making (certain detail on the map shall be found on a certain position with accuracy of $\pm 0,5 \mathrm{~mm}$ depending upon the map scale).
Researches for geometric accuracy evaluation of points position were carried out by using of Pathfinder PRO XRS (Trimble) single-frequency GPS receiver and WAAS differential correction from EGNOS satellite system as well as by means of Terrasync and Pathfinder office 2.9 software. Four points (Tab. 2), navigation light constructions being situated along the very coastal line of the bay, were set for determination of the most possible values of horizontal differences.

Table 2 Calculation of corrections which should be applied to the positions obtained by means of GPS during plotting to the navigation chart of Boka Kotorska (scale 1:25 000)

\begin{tabular}{|c|c|c|c|c|}
\hline & \multicolumn{2}{|c|}{ Lights Points Positions $(\varphi, \lambda)$} & \multicolumn{2}{|c|}{ Difference: Besel - WGS84 } \\
\hline Fixed Points & BESEL & WGS84 & In arc seconds & In metres \\
\hline $\begin{array}{l}\text { Light } \\
\text { - Lepetane (Verige) }\end{array}$ & $\begin{array}{l}\varphi=42^{\circ} 28^{\prime} 03^{\prime \prime}, 87 \mathrm{~N} \\
\lambda=18^{\circ} 41^{\prime} 25^{\prime \prime}, 45 \mathrm{E}\end{array}$ & $\begin{array}{l}\varphi=42^{\circ} 28^{\prime} 05^{\prime \prime}, 17 \mathrm{~N} \\
\lambda=18^{\circ} 41^{\prime} 07^{\prime \prime}, 16 \mathrm{E}\end{array}$ & $\begin{aligned} \Delta \varphi & =-01,30 \\
\Delta \lambda & =18,29\end{aligned}$ & $\begin{array}{l}\Delta \varphi=-40,0 \\
\Delta \lambda=418,0\end{array}$ \\
\hline $\begin{array}{l}\text { Light } \\
\text { - Staničić } \\
\text { (Tivat) }\end{array}$ & $\begin{array}{l}\varphi=42^{\circ} 25^{\prime} 48^{\prime \prime}, 05 \mathrm{~N} \\
\lambda=18^{\circ} 42^{\prime} 00^{\prime \prime}, 81 \mathrm{E}\end{array}$ & $\begin{array}{l}\varphi=42^{\circ} 25^{\prime} 49^{\prime \prime}, 05 \mathrm{~N} \\
\lambda=18^{\circ} 41^{\prime} 42^{\prime \prime}, 56 \mathrm{E}\end{array}$ & $\begin{aligned} \Delta \varphi & =-01,00 \\
\Delta \lambda & =18,25\end{aligned}$ & $\begin{array}{l}\Delta \varphi=-31,0 \\
\Delta \lambda=417,0\end{array}$ \\
\hline $\begin{array}{l}\text { Light } \\
\text { - Oko (Krtole) }\end{array}$ & $\begin{array}{l}\varphi=42^{\circ} 24^{\prime} 21^{\prime \prime}, 51 \mathrm{~N} \\
\lambda=18^{\circ} 40^{\prime} 15^{\prime \prime}, 69 \mathrm{E}\end{array}$ & $\begin{array}{l}\varphi=42^{\circ} 24^{\prime} 22^{\prime \prime}, 62 \mathrm{~N} \\
\lambda=18^{\circ} 39^{\prime} 57^{\prime \prime}, 97 \mathrm{E}\end{array}$ & $\begin{aligned} \Delta \varphi & =-01,11 \\
\Delta \lambda & =17,72\end{aligned}$ & $\begin{aligned} \Delta \varphi & =-34,0 \\
\Delta \lambda & =405,0\end{aligned}$ \\
\hline $\begin{array}{l}\text { Light } \\
\text { - Njivice } \\
\text { (H.Novi) }\end{array}$ & $\begin{aligned} \varphi & =42^{\circ} 26^{\prime} 05^{\prime \prime}, 20 \mathrm{~N} \\
\lambda & =18^{\circ} 31^{\prime} 20^{\prime \prime}, 84 \mathrm{E}\end{aligned}$ & $\begin{array}{l}\varphi=42^{\circ} 26^{\prime} 06^{\prime \prime}, 37 \mathrm{~N} \\
\lambda=18^{\circ} 31^{\prime} 03^{\prime \prime}, 16 \mathrm{E}\end{array}$ & $\begin{aligned} \Delta \varphi & =-01,17 \\
\Delta \lambda & =17,68\end{aligned}$ & $\begin{array}{l}\Delta \varphi=-36,0 \\
\Delta \lambda=404,0\end{array}$ \\
\hline
\end{tabular}

Corrections, which should be added to the "satellite" position coordinates during plotting to the navigation chart of Boka Kotorska, were determined according to the obtained data (Tab. 2), and the following warning was written on the map: "Positions, obtained by means of satellite navigation systems such as GPS, refer to WGS84 datum. Obtained positions in this way, before plotting to this map, should be moved to the EAST for 0,30 minutes and to the SOUTH for 0,02 minutes."

Corrections were determined according to Eqs. (1) and (2):

$$
\begin{aligned}
& \frac{\sum \Delta \lambda}{4}=\frac{71,94^{\prime \prime}}{4}=17,99^{\prime \prime} \approx 0,30^{\prime} \approx 411 \text { metres, } \\
& \frac{\sum \Delta \varphi}{4}=\frac{4,58^{\prime \prime}}{4}=1,15^{\prime \prime} \approx 0,02^{\prime} \approx 37 \text { metres. }
\end{aligned}
$$

The second part of evaluation of geometric horizontal map accuracy was expressed by deviation of points on the map from their real position. Taking into consideration that it is practically impossible to know "true" values of point positions i.e. their parameters $X$ and $Y(\varphi$ and $\lambda)$, they are substituted by adequately possible values which are obtained in the field and compared to the values which are read on the map. During field works, for evaluation of horizontal accuracy of digital atlas navigation chart of Boka Kotorska, eleven points of navigation safety objects, navigation lights being situated on the coast of Boka Kotorska (Tab. 3), were totally set. The above mentioned equipment was used for determination of values ( $\varphi$ and $\lambda$ ), and all measurements were done with accuracy which meets the level of necessary cartographic calculations. Obtained values can be accepted for certain cartographic calculations in order to get the most possible representation about geometric map accuracy.
Evaluation of horizontal accuracy refers to certain points on the map, but it can essentially apply to the horizontal accuracy of coastal line of the Gulf as an element of geographic map contents. All navigation lights in the Gulf are situated on the built coast along the very line which separates the land from the sea. As a standard of horizontal accuracy, mean squared error $\left(m_{x}\right.$ and $\left.m_{y}\right)$ on coordinate axes is taken, and it is calculated according to Eq. (3):

$m_{x}= \pm \sqrt{\frac{\sum \varepsilon_{x}^{2}}{n}} ; m_{y}= \pm \sqrt{\frac{\sum \varepsilon_{y}^{2}}{n}}$

where $\varepsilon_{x}$ and $\varepsilon_{y}$ refer to the exception of coordinates of points which can be accurately identified.

Absolute mean squared error $\left(m_{p}\right)$ was calculated according to Eq. 4:

$m_{p}= \pm \sqrt{m_{x}^{2}+m_{y}^{2}}= \pm \sqrt{\frac{\sum \varepsilon_{x}^{2}+\sum \varepsilon_{y}^{2}}{n}}$.

By inserting the values from Tab. 3 in the mentioned formulas, the following mean squared errors on the coordinate axes, $m_{x}= \pm 7,50$ meters and $m_{y}= \pm 6,15$ meters and absolute mean squared error amounting $m_{p}=$ $\pm 9,70$ meters were obtained. This can be applied to the evaluation of horizontal accuracy of navigation safety objects as well as to the evaluation of planimetric accuracy of coastal line of the Gulf. By research and evaluation of position accuracy of certain geographic elements of atlas navigation chart as well as according to the other values i.e. indicators of fitting into maps and georeferencing, it can be concluded that accuracy of the other elements ranges within the limits of 0,2 to $0,4 \mathrm{~mm}$ 
which amounts from 5 to 10 meters at a map scale. Greater accuracy would be surely achieved if authentic basic cartographic sources were possessed during research, and not only editorial copies. Even after all done activities in the procedure of obtaining of digital products as well as inevitable deformations which occur (during scanning, transformations, etc.), it is, however, possible to come to higher quality, more applicable and in a certain sense more accurate digital cartographic product which has its broader application and not only in making possible safe navigation.

Table 3 Calculation of differences of 11 fixed point coordinates (true errors) in order to evaluate horizontal accuracy of certain map elements

\begin{tabular}{|c|c|c|c|c|}
\hline \multirow{2}{*}{\begin{tabular}{|c|} 
\\
\end{tabular}} & \multirow[b]{2}{*}{ Measured on the chart } & \multirow[b]{2}{*}{ "True" values } & \multicolumn{2}{|c|}{$\begin{array}{l}\text { Absolute differences } \\
\text { (measured - "true") }\end{array}$} \\
\hline & & & In arc seconds & In metres \\
\hline 1. Light Lepetane & $\begin{aligned} \varphi & =42^{\circ} 28^{\prime} 04^{\prime \prime}, 00 \mathrm{~N} \\
\lambda & =18^{\circ} 41^{\prime} 25^{\prime \prime}, 88 \mathrm{E}\end{aligned}$ & $\begin{array}{l}\varphi=42^{\circ} 28^{\prime} 03^{\prime \prime}, 87 \mathrm{~N} \\
\lambda=18^{\circ} 41^{\prime} 25^{\prime \prime}, 45 \mathrm{E}\end{array}$ & $\begin{array}{l}\Delta \varphi=0,13 \\
\Delta \lambda=0,43\end{array}$ & $\begin{array}{l}\Delta \varphi=4,01 \\
\Delta \lambda=9,83\end{array}$ \\
\hline 2. Light Donji Krašići & $\begin{array}{l}\varphi=42^{\circ} 24^{\prime} 32^{\prime \prime}, 16 \mathrm{~N} \\
\lambda=18^{\circ} 39^{\prime} 27^{\prime \prime}, 03 \mathrm{E}\end{array}$ & $\begin{array}{l}\varphi=42^{\circ} 24^{\prime} 32^{\prime \prime}, 37 \mathrm{~N} \\
\lambda=18^{\circ} 39^{\prime} 27^{\prime \prime}, 43 \mathrm{E}\end{array}$ & $\begin{array}{l}\Delta \varphi=0,21 \\
\Delta \lambda=0,40\end{array}$ & $\begin{array}{l}\Delta \varphi=6,48 \\
\Delta \lambda=9,14\end{array}$ \\
\hline 3. Light Gat Bijela & $\begin{array}{l}\varphi=42^{\circ} 27^{\prime} 14^{\prime \prime}, 59 \mathrm{~N} \\
\lambda=18^{\circ} 39^{\prime} 56^{\prime \prime}, 18 \mathrm{E}\end{array}$ & $\begin{array}{l}\varphi=42^{\circ} 27^{\prime} 14^{\prime \prime}, 86 \mathrm{~N} \\
\lambda=18^{\circ} 39^{\prime} 56^{\prime \prime}, 35 \mathrm{E}\end{array}$ & $\begin{array}{l}\Delta \varphi=0,27 \\
\Delta \lambda=0,17\end{array}$ & $\begin{array}{l}\Delta \varphi=8,34 \\
\Delta \lambda=3,88\end{array}$ \\
\hline 4. Light Oko (Bjelila) & $\begin{array}{l}\varphi=42^{\circ} 24^{\prime} 21^{\prime \prime}, 38 \mathrm{~N} \\
\lambda=18^{\circ} 40^{\prime} 15^{\prime \prime}, 25 \mathrm{E}\end{array}$ & $\begin{array}{l}\varphi=42^{\circ} 24^{\prime} \quad 21^{\prime \prime}, 51 \mathrm{~N} \\
\lambda=18^{\circ} 40^{\prime} 15^{\prime \prime}, 69 \mathrm{E}\end{array}$ & $\begin{array}{l}\Delta \varphi=0,13 \\
\Delta \lambda=0,44\end{array}$ & $\begin{array}{c}\Delta \varphi=4,01 \\
\Delta \lambda=10,05\end{array}$ \\
\hline 5. Light Pristan & $\begin{array}{l}\varphi=42^{\circ} 25^{\prime} 31^{\prime \prime}, 29 \mathrm{~N} \\
\lambda=18^{\circ} 36^{\prime} 24^{\prime \prime}, 88 \mathrm{E}\end{array}$ & $\begin{array}{l}\varphi=42^{\circ} 25^{\prime} 31^{\prime \prime}, 60 \mathrm{~N} \\
\lambda=18^{\circ} 36^{\prime} 24^{\prime \prime}, 39 \mathrm{E}\end{array}$ & $\begin{array}{l}\Delta \varphi=0,31 \\
\Delta \lambda=0,49\end{array}$ & $\begin{array}{c}\Delta \varphi=9,56 \\
\Delta \lambda=11,20\end{array}$ \\
\hline 6. Light Rose & $\begin{array}{l}\varphi=42^{\circ} 25^{\prime} 38^{\prime \prime}, 73 \mathrm{~N} \\
\lambda=18^{\circ} 33^{\prime} 41^{\prime \prime}, 48 \mathrm{E}\end{array}$ & $\begin{array}{l}\varphi=42^{\circ} 25^{\prime} 38^{\prime \prime}, 60 \mathrm{~N} \\
\lambda=18^{\circ} 33^{\prime} 41^{\prime \prime}, 13 \mathrm{E}\end{array}$ & $\begin{array}{l}\Delta \varphi=0,13 \\
\Delta \lambda=0,35\end{array}$ & $\begin{array}{l}\Delta \varphi=4,01 \\
\Delta \lambda=8,00\end{array}$ \\
\hline 7. Light Njivice gat & $\begin{array}{l}\lambda=42^{\circ} 26^{\prime} 05^{\prime \prime}, 16 \mathrm{~N} \\
\lambda=18^{\circ} 31^{\prime} 20^{\prime \prime}, 67 \mathrm{E}\end{array}$ & $\begin{array}{l}\varphi=42^{\circ} 26^{\prime} 05^{\prime \prime}, 20 \mathrm{~N} \\
\lambda=18^{\circ} 31^{\prime} 20^{\prime \prime}, 84 \mathrm{E}\end{array}$ & $\begin{aligned} \Delta \varphi & =0,04 \\
\Delta \lambda & =0,17\end{aligned}$ & $\begin{array}{l}\Delta \varphi=1,23 \\
\Delta \lambda=3,88\end{array}$ \\
\hline 8. Light Baošići & $\begin{array}{l}\varphi=42^{\circ} 26^{\prime} 24^{\prime \prime}, 73 \mathrm{~N} \\
\lambda=18^{\circ} 38^{\prime} 03^{\prime \prime}, 81 \mathrm{E}\end{array}$ & $\begin{array}{l}\varphi=42^{\circ} 26^{\prime} \quad 24^{\prime \prime}, 63 \mathrm{~N} \\
\lambda=18^{\circ} 38^{\prime} 03^{\prime \prime}, 45 \mathrm{E}\end{array}$ & $\begin{array}{l}\Delta \varphi=0,10 \\
\Delta \lambda=0,36\end{array}$ & $\begin{array}{l}\Delta \varphi=3,09 \\
\Delta \lambda=8,23\end{array}$ \\
\hline 9. Light Kostanjica & $\begin{array}{l}\varphi=42^{\circ} 29^{\prime} 10^{\prime \prime}, 95 \mathrm{~N} \\
\lambda=18^{\circ} 40^{\prime} 16^{\prime \prime}, 07 \mathrm{E}\end{array}$ & $\begin{array}{l}\varphi=42^{\circ} 29^{\prime} 10^{\prime \prime}, 60 \mathrm{~N} \\
\lambda=18^{\circ} 40^{\prime} 16^{\prime \prime}, 10 \mathrm{E}\end{array}$ & $\begin{array}{l}\Delta \varphi=0,35 \\
\Delta \lambda=0,03\end{array}$ & $\begin{array}{c}\Delta \varphi=10,81 \\
\Delta \lambda=0,69\end{array}$ \\
\hline 10. Light Lipci & $\begin{array}{l}\varphi=42^{\circ} 29^{\prime} 45^{\prime \prime}, 71 \mathrm{~N} \\
\lambda=18^{\circ} 39^{\prime} 51^{\prime \prime}, 47 \mathrm{E}\end{array}$ & $\begin{array}{l}\varphi=42^{\circ} 29^{\prime} 45^{\prime \prime}, 86 \mathrm{~N} \\
\lambda=18^{\circ} 39^{\prime} 51^{\prime \prime}, 72 \mathrm{E}\end{array}$ & $\begin{array}{l}\Delta \varphi=0,15 \\
\Delta \lambda=0,25\end{array}$ & $\begin{array}{l}\Delta \varphi=4,63 \\
\Delta \lambda=5,71\end{array}$ \\
\hline 11. Light Perast-Penčić & $\begin{array}{l}\varphi=42^{\circ} 29^{\prime} 14^{\prime \prime}, 27 \mathrm{~N} \\
\lambda=18^{\circ} 42^{\prime} 05^{\prime \prime}, 90 \mathrm{E}\end{array}$ & $\begin{array}{l}\varphi=42^{\circ} 29^{\prime} 14^{\prime \prime}, 40 \mathrm{~N} \\
\lambda=18^{\circ} 42^{\prime} 05^{\prime \prime}, 65 \mathrm{E}\end{array}$ & $\begin{array}{l}\Delta \varphi=0,13 \\
\Delta \lambda=0,25\end{array}$ & $\begin{array}{l}\Delta \varphi=4,01 \\
\Delta \lambda=5,71\end{array}$ \\
\hline
\end{tabular}

\subsection{Procedure of atlas chart creating by GIS application}

Atlas map making by GIS application implied analysis of all mathematical elements of the basic cartographic sources and also detailed calculation and checking of mathematical elements especially for navigation chart of the Boka Kotorska Gulf. Scanning, registration i.e. georeferencing of raster images of the basic sources in Mercator projection were done, and after that, definition and generation of working version frames of digital atlas maps of the Boka Kotorska Gulf were made. Based on the realized field works, evaluation of geometric accuracy of atlas navigation chart of Boka Kotorska was done.

Having completely defined geographic map contents, scanned, collected and chosen of all necessary data sources which will serve as the aid during cartographic modelling, georefenced (registrated) maps within GIS and defined working geospace, it was approached to the stage of generating map contents representing the important part of the making procedure of the new maps i.e. modified ones. This stage mostly depends on the level of training, ability and creativity of a cartographer to apply all possibilities and completely use achievements which GIS software and modern computer technique offer. Further stages of atlas map making imply map structuring, layer creation, then topological processing, correction and developing of maps (allocation of colours to the specific areas, digital display of $2 \mathrm{D}$ and $3 \mathrm{D}$ models). Within GIS, the so-called map printing is possible upon request (printing on demand) and relatively simple updating as well as new data addition.

\section{Research results}

Within research cartographic project of Digital atlas of the Boka Kotorska Gulf, geographic information and data were converted into vector data formats making possible modelling and lay-out presentation of phenomena and objects by GIS application. So far, twelve working versions have been made of thematic atlas charts within atlas (overview maps, thematic bathymetric and sedimentary maps, navigation charts) using system of derived maps, and geographic contents of navigation atlas charts is mostly adapted to the instructions, recommendations and resolutions of relevant international institutions [1, 4] and organizations such as the International Hydrographic Organization and International Maritime Organization. In favour of this, there is the fact that navigation chart of Boka Kotorska was officially published at a scale 1: 25000 during 2011 by the Hydro meteorological Department of the Republic of Montenegro, which was made practically from specialized research and project of Digital atlas of Boka Kotorska. 


\section{Conclusion}

Once digital atlas charts of Boka Kotorska were made within GIS, they can have more purposes and can be observed from more aspects: position-navigational aspect (aspect of improving navigation transportation safety), scientific-geographic aspect, economic and legal aspect of certain atlas maps and cultural-educational aspect. The advantages of this automatic way of atlas map creating within GIS are reflected in the possibility of simultaneous carrying out and realization of more goals at the practically same time. It means that once obtained digital vector data can be used for creating and filling of spatial geocoded data bases as the basis of marine GIS as well as possible initial basis for creating specific electronic navigation nautical maps. Also, there is the possibility of obtaining different thematic graphical reviews of spatial elements of the Boka Kotorska Gulf, i.e. possibility of making digital model of relief, relief of the sea bottom and/or making of different thematic maps due to the fact that the contents is maximally dissected by layers.

\section{$6 \quad$ Literature}

[1] Chart Specification of the IHO and Regulation of the IHO for INT charts. Publication M-4. International Hydrographic Bureau (IHB). Monaco, 1988.

[2] Frančula, N. Digital Cartography, University of Zagreb, Faculty of Geodesy, Croatia, Zagreb, 1999.

[3] Janata, T.; Seemann, P.; Cajthaml, J.; Zimova, R. Designing Maps for a New Thematic Atlas of the Czech History. // XXVI International Cartographic Conference Proceedings. Dresden. The Web version (2013), http://icaci.org/files/documents/ICC_proceedings/ICC2013/ extendedAbstract/337 proceeding.pdf (05.04.2014)

[4] Names and Limits of Oceans and Seas. Special Publication No. 23, 4th Edition. International Hydrographic Bureau (IHB). Monaco, 2002.

[5] Nautical tables. The Third Adapted Edition. Hydrographic Institute of Yugoslav Navy (HIJRM). SFR Yugoslavia. Split, 1978

[6] Nautical Chart of Boka Kotorska, scale 1:25 000 . Hydrographic Institute of Yugoslav Navy (HIJRM). SFR Yugoslavia, Split, 1962.

[7] Nautical Chart of the Adriatic Sea, scale 1:1 100000. United Kingdom Hydrographic Office, 1988.

[8] Nautical Chart of Budva - Dubrovnik, scale 1:100 000. Hydrographic Institute of Navy. Federal Republic of Yugoslavia. Lepetane 2002

[9] Nautical Chart of the Adriatic Sea, scale 1:1 000000. Hydrographic Institute of Yugoslav Navy (HIJRM). SFR Yugoslavia. Split, 1973.

[10] Nautical Chart of the Adriatic Sea, the central and southern part of the Adriatic Sea, scale 1:750 000. Hydrographic Institute of Yugoslav Navy (HIJRM). SFR Yugoslavia. Split, 1984.

[11] Nautical Chart of Kotor, scale 1:80 000. Hydrographic Institute of Yugoslav Navy (HIJRM). SFR Yugoslavia. Split, 1983.

[12] Perez, M. Traditional Cartography. Course on Nautical Cartography. International Maritime Academy. Italy, Trieste, 2001.

[13] Peterca, M.; Radošević, N.; Milisavljević, S.; Racetin, F. Cartography. Military Geographic Institute. Serbia, Belgrade, 1974.

[14] Pucher, A.; Kriz, K.; Katzlberger, G. Atlas Information System of Austria. // XXIII International Cartographic
Conference. Moscow. The Web version (2007) http://icaci.org/files/documents/ICC_proceedings/ICC2007/ $\mathrm{html} /$ Proceedings.htm (03.04.2014)

[15] Sedimentary Atlas of the Adriatic Sea. Hydrographic Institute of Yugoslav Navy (HIJRM). SFR Yugoslavia, Split, 1985.

[16] Sieber, R.; Hollenstein, L.; Odden, B.; Hurni, L. From Classic Atlas Design to Collaborative Platforms: The SwissAtlasPlatform Project. // XXV International Cartographic Conference. Paris. The Web version (2011), http://icaci.org/files/documents/ICC proceedings/ICC2011/ Oral\%20Presentations\%20PDF/D2-National\%20and\%20 regional\%20atlases/CO-344.pdf (02.04.2014)

[17] Stamenković, N. Digital Atlas of Hydrographic Phenomena in Boka Kotorska as a basis for development marine GIS. Master Thesis. University of Belgrade, Faculty of Geography, Serbia, Belgrade, 2004.

[18] Wright, D. J.; Dwyer, N.; Cummins, W. Coastal Informatics: Web Atlas Design and Implementation. Book published in the USA by Information Science Reference (an imprint of IGI Global), Hershey, New York, 2011.

[19] Živković, D.; Jovanović, J. Cartographic Conversion of Geospatial Data. // Conference Proceedings, LV Volume. The Faculty of Geography / Serbia, Belgrade, 2007, pp. 175-184.

\section{Authors' addresses}

Nikola Stamenković, PhD

Ministarstvo odbrane

Ul. Nemanjina 15, 11000 Beograd, Serbia

E-mail: stnikola2@yahoo.com

Svetislav Šoškić, MSc

Ministarstvo odbrane, Vojna akademija

U1. Generala Pavla Jurišića Šturma 33, 11000 Beograd, Serbia

E-mail: cacaksole@yahoo.com

Miodrag Kostić, PhD

Ministarstvo odbrane

Ul. Nemanjina 15, 11000 Beograd, Serbia

E-mail: kmiodrag@ikomline.net

Ljubomir Gigović, PhD

Ministarstvo odbrane, Vojna akademija

Ul. Generala Pavla Jurišića Šturma 33, 11000 Beograd, Serbia E-mail: ljgigovic@yahoo.com

\section{Miodrag Regodić, PhD}

Ministarstvo odbrane, Vojna akademija

U1. Generala Pavla Jurišića Šturma 33, 11000 Beograd, Serbia E-mail: mregodic62@gmail.com

Saša Bakrač, PhD

Ministarstvo odbrane, Vojnogeografski institut U1. Mije Kovačevića 5, 11000 Beograd, Serbia

E-mail: sbakrac@yahoo.com 